\title{
Governmentality - Neoliberalism - Education: the Risk Perspective
}

\author{
Ondrej Kaščák, Branislav Pupala
}

Abstract: This paper understands the basic elements of neoliberalism in education and governmentality to be the technologies for the neoliberal government of education. It outlines Foucault's methodology for analysing governmentality and shows how neoliberalism is a discursive formation which homogenises apparently unrelated language games and discourses. It places particular emphasis on the rhizomatic dispersion of neoliberal discursive and non-discursive practices, which in the end create a mosaic of thinking and acting with its own existing internal logic. This paper provides a cross-sectional perspective on how neoliberalism has implanted itself as a universal phenomenon along the horizontal and vertical lines of the education sphere and shows how, particularly through the policy of lifelong learning for a knowledge society, it is transforming first of all the education of adults and how subsequently it has become a fundamental blueprint for the complex revision of higher education and regional schooling, including pre-school education. This paper prefaces this single-issue edition of the Journal of Pedagogy and therefore presents and summarises the articles published in this issue, and suggests how they are thematic examples of a single and more general theoretical framework.

Key words: neoliberalism, governmentality, educational discourses, rhizome metaphor, lifelong learning policy, neoliberalism and universities, neoliberalism in preschool and school education

\section{Dispersion analysis}

If we consider the theme of education in the light of such concepts as 'governmentality' and 'neoliberalism', then we mark out a trajectory which in

1 The research and this single-issue edition of the Journal of Pedagogy are the outcome of two grants: VEGA 1/0224/11 Archeology of neoliberal governmentality in contemporary educational policy and in educational theory, and VEGA 1/0172/09 Changes of a school environment with respect to the reproduction of cultural literacy. 
recent history has not been familiar to pedagogical thinking in central Europe. 'Governmentality' implies social and political government, while 'neoliberalism' points to the particular economic rationality that underlies it. We thus find ourselves making our way around the edge of a socioeconomic framework that has since 1989 always remained somewhat in the background of the pedagogical thinking to be found in this part of the world, due to the conviction that the communist metanarrative had lost its legitimacy and that it had been replaced instead by many coexisting smaller narratives expressing a local and communitarian way of life within a democratic society. Pedagogical research has therefore dealt primarily with the internal dynamics of the education sector, whether that be on a philosophical level analysing the phenomenology of the relations between the actors involved in learning or at the psychological level analysing the nature of the school climate, atmosphere or the subjective world of those who participate in education (for instance in the form of the naïve ideas pupils hold or perceptions on the teaching profession, and so forth). The legitimacy of the many coexisting pedagogical narratives has led to educational interest in many alternative forms of education and schools and many 'interested parties' from various sections of society have become involved in education. This interest has changed the manner in which education is organised in that as a result of the measures introducing a double curriculum (which is completely new for central Europe) the state has formally been dethroned from its position of running education. It would seem that education is responding to 'postmodernity':

"Simplifying to the extreme, I define postmodern as incredulity toward metanarratives. This incredulity is undoubtedly a product of progress in the sciences: but that progress in turn presupposes it. To the obsolescence of the metanarrative apparatus of legitimation corresponds, most notably, the crisis of metaphysical philosophy and of the university institution which in the past relied on it. The narrative function is losing its functors, its great hero, its great dangers, its great voyages, its great goal. It is being dispersed in clouds of narrative language elements-narrative, but also denotative, prescriptive, descriptive, and so on" [Lyotard 1984: xxiv].

\section{Neoliberalism as a discursive formation}

At this point we shall pause to entertain ourselves with notions of which description of society we should believe and whether pedagogy really has found the 'postmodern' version to be convincing. This is an issue which also has serious methodological consequences. The death of the 'metanarrative', which underlies 'the postmodern condition', legitimises the rivalry between 
the different pedagogical language games. The question is whether there might not be a (new) agent operating in the background, which arranges them into a particular structure of relations and connections. And here we come to Michel Foucault. In an archaeological sense of the word, he reflects on a "pre-conceptual level, the field in which concepts can coexist" [Foucault 2002: 94]. This level may allow what he calls "discursive formations" to emerge. This occurs in situations "whenever one can describe, between a number of statements, such a system of dispersion, whenever between objects, types of statement, concepts, or thematic choices, one can define a regularity (an order, correlations, positions and functionings, transformations)" [Foucault 2002: 62]. Foucault's approach, unlike that of Lyotard is archeological. It is not enough to postulate the end of the metanarrative, it is important to track what happens consequently with discourses, what kind of relations are constituted between them and what kind of discursive formations they create. This means establishing what kind of mentality or rationality (Foucault talks of the episteme) influences the creation of meaningful statements in a particular sector of social government.

This governmentality represents the "ensemble formed by the institutions, procedures, analyses, and reflections, the calculations and tactics that allow the exercise of this very specific albeit very complex form of power" [Foucault 2000b: 64]. From the considerable work conducted in the area of governmental studies in education [Bröckling, Krasmann, Lemke 2000; Dzierzbicka 2006; The Learning Society from the Perspective of Governmentality 2006; Neoliberalism and Education 2007; Peters, Besley, Olssen, Maurer, Weber, 2009; Weber, Maurer 2006] it is clear that the discursive formation of neoliberalism is shaping the current governmentality controlling education.

Towards the end of the 1970s, Foucault had already contemplated the emerging pragmatics of social government: "in this perspective and continuing with the analysis of liberal governmentality, I would like to see how it appears and reflects upon itself, how at the same time it is brought into play and analyses itself, how, in short, it currently programs itself" [2000c: 70]. Foucault had already noted the comprehensive penetration of liberalism into the spheres of social and individual life. He argued that "American liberalism is not...just an economic and political choice formed and formulated by those who govern and in the governmental milieu" it is a "whole way of being and thinking. It is a type of relation between the governors and the governed much more than a technique of governors with regard to the governed." "I think this is why American liberalism currently not just, or not just so much as a political alternative, but let's say as a sort of manysided, ambiguous, global claim with a foothold in both the right and the 
left. It is also a method of thought, a grid of economic and social analysis... Liberalism must be a general style of thought, analysis, and imagination." [2009: 192-193]. Liberalism is a "specific economic discourse or philosophy which has become dominant and effective in world economic relations as a consequence of super-power sponsorship. Neoliberalism is a politically imposed discourse, which is to say that it constitutes the hegemonic discourse of western nation states" [Olssen, Peters 2005: 314]. As Olssen and Peters [2005: 315] have noted, the neoliberalism of today is not completely identical to classical liberalism. The promulgation of the economization of the social does not in fact mean the simple negation of the state and its disbanding through the rules of the market. Rather it refers to the economic vassalage of the state, that is "a positive conception of states role in creating the appropriate market by providing the conditions, laws and institutions necessary for its operation. In classical liberalism the individual is characterized as having an autonomous human nature and can practice freedom. In neoliberalism the state seeks to create an individual that is an enterprising and competitive entrepreneur." It is in this format that neoliberalism today forms the basis of social reality, the episteme.

\section{The rhizomatic dispersion of neoliberal governmentality}

Neoliberalism is the new metanarrative. Arriving at this narrative and its hegemonisation has taken over 30 years, dispersed both in time and space: "Some states are only just now experiencing the first pressures towards neoliberalism (for example Chile), some have adopted it only in small part (for example Sweden) and others have deliberately and thoroughly installed neoliberal practices and principles over the last 20-30 years (and this includes Australia and New Zealand)" [Davies and Bansel 2007: 250]. Central Europe and Scandinavia are places where this metanarrative has only recently begun to produce fertile ground for pedagogical discourse. In this environment, neoliberalism is moving from the level of unreflected discursive connections to the level of manifestation, and it is being channelled by the European Union policies on schooling and education. This perspective is the subject of analysis in the article by D. Gillies, S. Štech and M. Kopecký in this issue of the Journal of Pedagogy. The authors illustrate the many nuances of contemporary neoliberal totality in European education policy.

The seemingly fragmented nature of contemporary pedagogical discourse in many of the language games found in the Visegrád Four countries (the Slovak Republic, the Czech Republic, Hungary and Poland) does not indicate a lack of coherence. Decentralisation in education, the interlinking of local and community in education, consideration of educational alterna- 
tives, a leaning towards the internal psychological dynamic of the education process, in teaching and life at school may all be reactions to the newly constituted form of pedagogical rationality postulating the end of state and centralised interventionism that proffers new visions of individualisation and subjectivisation. The logic of "decentrism" [Hultqvist 1996] is in many of its current forms a neoliberal logic. This shift is highlighted in this single-issue journal in the article by L. Pongratz, one of the few writing on education who has since 1987 been focusing on how the ideas of Michel Foucault can be applied to education. It concerns the underpinnings of authority, since more systematic Foucauldian analyses on education first began appearing in pedagogy in the 1990s. Pongratz shows how the fragmentary nature of pedagogical discourse at a time of educational reforms and the weakening of the centralised control of education and power goes hand in hand with instituting the strategy of 'soft power' and the emergence of a new mode of "societies of control" based on self-control and the mechanisms of control of their internal dynamics. These mechanisms correspond to the metanarrative of neoliberalism and thus represent a new form of governmentality in the school sector. At the same time Pongratz warns that these mechanisms are leading a fundamental ontological transformation. As Foucault states [2000a: 153] "in the idea of governmentality I am aiming at the totality of practices, by which one can constitute, define, organize, instrumentalize the strategies which individuals in their liberty can have in regard to each other". In relation to this Davies and Bansel [2007: 248] note that "people are reconfigured as productive economic entrepreneurs of their own lives. We suggest it is primarily this reconfiguration of subjects as economic entrepreneurs, and institutions capable of producing them, which is central to understanding the structuring of possible fields of action that has been taking place with the installation of neoliberal modes of governance."

This redefinition and ontological transformation is not the consequence of a monolithic, always clear and easily identifiable block of power operating under the label of some kind of liberalism per se. The article by F. Nxumalo, V. Pacini-Ketchabaw a M. C. Rowan in this issue points this fact out: "By conceptualizing neoliberalism as assemblages, we avoid generalized explanations of neoliberalism as an overarching system or machinic totality that simply shapes subjects. In our analysis, we seek to create disruptions in this conceptualization by confronting neoliberalisms on their slippery territory, making visible the subjectivities they produce as they affectively impinge on possibilities for action". The neoliberal metanarrative thus represents a totality of a variety of discursive and non-discursive practices, which often operate disparately, subliminally and diversely. It is not a homogenous ideology, but rather a number of heterogeneous discourses and measures, 
which ultimately converge and strengthen one another. For this reason these authors adopt the terminology used by G. Deleuze and F. Guattari. The social permeation of neoliberalism throughout the social sphere can be linked to the metaphor of rhizome. A rhizome refers to a conception of an intermeshed system, adapted from biology, where roots grow from various parts of the stem. "Unlike centralised (or even polycentric) systems with hierarchical communication and predefined relations, the rhizome system is acentric, non-hierarchical and non-signifying; it has no General and no organisational memory" [Michalovič and Minár 1997: 220]. These roots are extremely numerous: the World Bank, the World Trade Organisation, OECD, the institutions of the EU, national governments, employers' organisations, private companies from various manufacturing and industrial sectors etc. Deleuze and Guattari, along with Foucault, have become the main authorities in analysing neoliberal discourses. This is evidenced in the fact that in this issue Pongratz bases his work on the writings of Deleuze, and so too do T. Webb and K. N. Gulson, who also incorporate the work of Guattari in their article. In addition, the article by Nxumalo, Pacini-Ketchabaw and Rowan also refers to Deleuze and Guattari. These two articles expose neoliberalism as a racial ideology disseminated through education with culturally devastating effects.

\section{Neoliberalism in the vertical and horizontal network of lifelong learning}

The fact that the neoliberal mentality is both ever-present and hegemonic means that what may at first seem to be a mosaic of different discourses is now starting to form a complete and coherent whole that seeks common aims. Neoliberalism links that which cannot be linked, for instance when it assimilated learner-centred pedagogies with the progressive humanist traditions of education to be used for human capital development. As Carter [2009: 59] argues: "There is no doubt that many of us would believe our promotion of learner-centred pedagogies as best practice within the humanist and progressive tradition of education rather than as culturally insensitive fodder for the global knowledge economy. But we need to recognise that there is more to it, and that neoliberal global discourses on education and knowledge economy have co-opted humanistic visions of active learning within democratic and collaborative environments to its own purposes of human capital development." The transition from the romanticist autonomous subject as held in the ideals of humanist pedagogy to the self-organising individual implementing decisions as an entrepreneurial (creative and flexible) subject is not in fact surprising; it is the logical development of ex- 
panding the self discourse into the realm of neoliberal rationality. Economic motives and the political backdrop fix the lens in such a way that the economic vision of OECD, WHO and the institutions of the EU is educationalized in notions of an active and self-conducting person, who represents both the goal and the means of the educationalized environment from a very young age to the end of his/her life and who represents capital for personal and social and economic prosperity alike. Part of this diffusion and particular discursive alliances may also be, as we are witness of in our own environment, the paradox of the educational policy of the OECD being the flag ship of the main protagonists of humanist education battling against the consequences of economic globalisation, individualism and consumerism.

The universal pervasion of the neoliberal mentality in the education sector does not affect pedagogical rhetoric alone; its impact is being carefully revealed (mostly through analyses like those conducted within governmental studies above) in particular segments of education systems, whether they are in the vertical education system or in the horizontal rhizomatic branches that transect the entire education sphere. The predominant and indeed the first branch of analysis on the neoliberal transformation of education responded to these horizontal factors of the transformation. It responded to a fundamental phenomenon which had a major impact on the all the elements relating to the way education had been understood and to the phenomenon of 'lifelong learning'. It also responded to the second wave of emphasis on lifelong learning [Rubenson 2008], which although it related mainly to adult education (thus, the economically productive section of the population), it enabled the radically changing picture of education to be understood in terms of the neoliberal conception of entrepreneurship. The thematic and methodological horizontality of the studies that emerged from research into policies of lifelong learning appeared precisely because the concept of lifelong learning itself was blurring the lines of educational institutions, and was de-institutionalising or rather re-institutionalising education [Tuschling and Engemann 2006] and totalising not only the time but also the space in which learning occurred. Neoliberalism was able to do this, since it had created the subject, the entrepreneurial self [Peters 2001], which is the driving unit behind economic production within this kind of society, primarily as the unit of human capital in a knowledge society. Since this subject is above all autonomous, flexible and sociable it is able to continuously learn and on the basis of personal responsibility and autonomy it can select appropriate learning opportunities and opportunities for continual self-development and provide evidence of those values. The ever-present lifelong learning environment is therefore a diffuse environment of possibilities, in which the autonomous subject shapes its success in terms of 
its own existence within the network of the entrepreneurial culture. Yet the concept of 'entrepreneurship' as a frame defining the nature of the subject and indeed the culture cannot be understood in strictly empirical or economic terms but as being fundamental. This is because this concept "refers to a kind of self-government within a particular governmental regime" [Simons and Masschelein 2008: 408]. Simons and Masschelein argue that a specific governmental regime connects three particular dimensions within entrepreneurship - the epistemological (primarily as the economisation of the social in the sense of penetrating these more distinct entities), strategic (primarily as technologies for provoking a response, for instance marketizing) and ethical (as a means of subjectivisation based on the entrepreneurial practice of freedom).

\section{The occupation of the institutional sector of school education}

The concept of lifelong learning as a specific technology of power and a global discourse on the entrepreneurship culture [Olssen 2006] underpins the expanding intricate network of the changing pedagogical discourse and the education sector and its units. It has penetrated into the ideas and decision-making processes at all levels of education - from the meaning and the goal of education, to the content of education, its organisation and control, our understanding of learning, and includes the relations between the different subjects of education and how these subjects see themselves. Although adult education was the first sector to be infused with the goal of adapting it to the need to prepare adaptable knowledge workers for the dynamic knowledge economy, it has become so extensive that it has also taken root in traditional institutions in the school sector at all levels from preschool to university. The intricate network which has been created within education, through the extension of neoliberalism, has established a specific discourse regime for the different levels of education, creating an education system that is now run along homogenised neoliberal lines.

Thorough and substantial analysis has been conducted into the transition of higher education and the universities under the dictates of the neoliberal technologies of power. In this issue, this perspective is represented by the work of R. Kemp and S. Stech. Kemp breathes new life into the work of Veblen from 1918 and directly addresses the risks of introducing a business mentality within the university environment on a broad basis. At the same time he touches on the legitimacy of the burgeoning colleges of business (formerly colleges of commerce) at American universities and shows how expanding this type of school has had a cumulative effect in that busi- 
ness principles are placed at the centre of university teaching and the life of the university as such. The development of model business training in universities to prepare the self-entrepreneurial subject for the labour market has disrupted the academic foundations of higher education. Paradoxically, however, the business schools themselves have been squeezed out of the curriculum, together with all the social sciences and economics courses, because in order to assure the personal successes of graduates on the labour market they have at best a supportive function. In addition to the fact that the business schools are becoming businesses within themselves, their cult has penetrated into the activities and the very existence of the entire university sector. Not long ago K. Liesmann [2009] outlined concisely and in the clearest of terms exactly what the impact of introducing this cult into European universities might mean, when he listed the pernicious consequences of transferring universities into an entrepreneurial regime. The advance of new managerial strategies for regulating the way universities are run and the education conducted within them is radically changing the character of them, and everything that relates to them is considered to be part of a strategic entrepreneurial mission. The managerial organisation of scientific knowledge at universities, stemming from the technologies regulating the knowledge society, has produced new criteria for the value of knowledge, in which "knowledge no longer represents a value in itself. Since knowledge is defined according to external criteria such as expectations, applications and usability, as is the case with manufactured products, we can expect that where something does not respond to these criteria, it will have to be swiftly eradicated" [Liessmann 2009: 98].

Simons' [Simons 2007] genealogical study of the transformation of (research) universities shows that the changes in this sector can be explained primarily as an epoch in the development of society embodying particular "intellectual technologies" and with its own particular conception as to its public mission. The current reforms of the universities come under the governmental milieu and although at the beginning they were hybrid institutions linking the technologies of the pastoral milieu with those of the governmental, they have predominantly become technologies of the second type - governmental. As Simons [2007: 441] has shown, governmental planning for European universities is based on particular intellectual technologies, of which one is a "collection of international statistics on performance indicators and benchmarks to objectify for example 'human capital and innovation gap'... in comparison to other countries, such as the USA, Canada and Japan". The highly competitive entrepreneurial environment is governed by a rich diversity of universities at all levels allowing for the utilisation of entrepreneurship education [Liesner 2006]. Those who are more critical, for 
instance S. Štech in this issue, point out that within Europe the Bologna Declaration, or at least what is left of it, has contributed to the adoration of a disproportionate commercialisation of the universities.

The rhizomatic shoots of neoliberalism spread throughout primary and secondary education in fact form a very rich mosaic. Research conducted in this area deals with different layers: from the consequences of introducing a relatively high level of autonomy into the running of schools; curricular policy in relation to the tensions arising between state and school over planned content; evaluating and defining the criteria for the quality of education; and finally, the preparation and professional development of teachers for these different levels of education. The current transformation of school education is based on universally implementing the neoliberal concept of lifelong learning along with the lifelong learning technologies associated with governmentality, even within the foundations of institutionalised school education. In the education arena, the approaches and technologies that produce the new knowledge workers are increasingly becoming the dominant and model configuration (the concepts of active and subjectively construed knowledge and creativity are becoming indispensable). The profile of the knowledge worker for a knowledge society has become the universal face and goal of general education. Models of so-called key competencies, which carefully represent this profile, have become the cornerstone for structuring the aims of general education and have enabled the content of education to be transformed into an entrepreneurial curriculum in the sense that all the previously noted dimensions of entrepreneurship - epistemological, strategic and ethical - are contained within it. Transforming the content of education in accordance with this regime means responding to neoliberal reality: "The curriculum must also be redesigned to reflect the new realities and the need for the highly skilled flexible worker who possesses requisite skills in management, information handling, communication, problem solving, and decision making. As the metanarrative has grown it has also been transformed to encompass a new emphasis on regional educational standards..." [Peters 2001: 66]. The regulation of regional standards in following this global framework of aims and content is, as was the case in further education, secured through the use of the particular intellectual technologies of the neoliberal milieu. These include the international assessment surveys such as PISA. Pongratz [2006], Uljens [2007] and others show how these international assessments serve primarily as instruments in the disciplinary and normalisation process, which as neoliberal technologies of power allow for the supranational regulation of education with the goal of increasing the competitive mentality that is beneficial to mutual trade. Autonomy, whether at the level of the education systems of the individual countries or in the 
schools themselves, is in fact an illusion, since the use of neoliberal technologies in managing education suggests rather that this process involves the re-centralisation and not the de-centralisation of these systems. More on this and other dimensions of the neoliberal education policy within regional education policy is to be found in the article by T. Webb and K. Gulson, who characterise neoliberal education policy as protofascist governmentality, and as far as school choice policies are concerned they argue that the neoliberal technologies of power used in the school sector are creating conditions for segregation based on performance along racist and ethnic lines. They show how global deregulation and marketization discourses are interconnected with the goals of local, national, and ultra-national raciologies.

\section{Neoliberal subjects of pre-school education}

In order to consider the issues thoroughly from a vertical perspective, we should mention how the reticular branches of neoliberalism begin crisscrossing at the very beginning - at the level of pre-school education. Some of these are considered in this issue by F. Nxumalo, V. Pacini-Ketchabaw and M. C. Rowan. This more global perspective on current pre-school education equally indicates that the impact of the policy of lifelong learning has been to strengthen the significance of pre-school education, since early childhood is now being considered as a holistic component in shaping abilities in lifelong learning in such a way that they dictate a competence profile of the knowledge worker. Pre-school education programmes, just like general education at all levels, are derived from the economic needs of the knowledge society and are an extension of preparation of the entrepreneurial subject from early childhood. Comparative analysis on reforms within pre-school education in Australia by Ailwood [2004] shows that since the 1990s pre-school education has been changing such that "the preparatory child is predominantly produced as a potential adult learner or earner. This is a shift from the more broadly dominant political rationality of a child being a developer who is potential rational adult" [Ailwood 2004: 30].

Let us leave for the moment the fact that the organisational governance of pre-school institutes is regulated by neoliberal technologies in much the same way as schooling at higher levels and that increasing commercialisation, privatisation and competitiveness in the pre-school institutional environment are seen as being significant tools for increasing their quality. There are a number of critical analyses on these regulatory instruments [for instance, Moss 2009]. We should, however, just mention that the rhizomatic discursive network of neoliberalism is creating a new image of the child, a new subject position that Holmer Nadesan [2002] describes as "the 
entrepreneurial infant" in her research. Holmer Nadesan shows how this image was initially created discursively through a combination of humanist psychology and the theory of human capital development against the backdrop of the information revolution, and today it is associated with the discursive regime of brain science linked to the new market for infant toys. The image of "the entrepreneurial infant" or the "superchild" has been incorporated into the creation of pre-school education programmes, standards and parental aspirations; at the same time, these aspirations and their consequences are "primarily driven by ascendance of the entrepreneurial, gold-collar 'knowledge worker', a new subject position that emerges at the intersection of contemporary discourses/practices of technology, entrepreneurial capitalism and consumer culture" [Holmer Nadesan 2002: 412].

\section{Conclusion}

In the region in which the Journal of Pedagogy is produced (Slovakia, and the wider postcommunist Central European region), this issue represents one of the collective sources which covers the issues of the impact of neoliberalism on education. In this region, there has quite clearly been a lack of analysis on this theme, despite the fact that the political, decision-making and indeed school bodies have almost unthinkingly allowed themselves to be carried along by neoliberal ideology, and pedagogical discourse is suffused through and through with it. Putting together this issue perhaps brings with it the opportunity to proffer a specific conceptual and methodological background to the analytical studies on the neoliberal governance of education and to highlight critical points concerning its application in educational policy and practice. Discussing neoliberalism in terms of the problematic area of the technologies of power is all the more significant today given that in the rather serious current economic crisis the "gold collar" elite are associated with the very background that produces and instils confidence in it.

\section{References}

Ailwood, J. 2004. Genealogies of Governmentality: Producing and Managing Young Children and Their Education. In The Australian Educational Research, 31 (3): 19-33. Bröckling, U., Krasmann, S., Lemke, T. (eds.). 2000. Gouvernementalität der Gegenwart.Studien zur Ökonomisierung des Sozialen.Frankfurt am Main: Suhrkamp.

Davies, B., Bansel, P. 2007. Neoliberalism and Education. In International Journal of Qualitative Studies in Education, 20 (3): 247-259.

Dzierzbicka, A. 2006. Vereinbaren statt anordnen: Neoliberale Gouvernementalität macht Schule.Wien: Löcker. 
Foucault, M. 2000a. Etika starostlivosti o seba samého ako prax slobody [The Ethic of Care for the Self as a Practice of Freedom]. In Foucault, M. Moc, subjekt a sexualita. Bratislava: Kalligram, 132-154.

Foucault, M. 2000b. Die Gouvernementalität. In Bröckling, U., Krasmann, S., Lemke, T. (eds.). Gouvernementalität der Gegenwart.Studien zur Ökonomisierung des Sozialen. Frankfurt am Main: Suhrkamp, 41-67

Foucault, M. 2000c. Staatsphobie. In Bröckling, U., Krasmann, S., Lemke, T. (eds.). Gouvernementalität der Gegenwart.Studien zur Ökonomisierung des Sozialen. Frankfurt am Main: Suhrkamp,68-71

Foucault, M. 2002. Archeologie vědění [The Archaeology of Knowledge]. Praha: Herman \& synové.

Foucault, M. 2009. Zrození biopolitiky [The Birth of Bio-politics]. Brno: CDK.

Holmer Nadesan, M. 2002. Engeneering the Entrepreneurial Infant: Brain Science, Infant Development Toys, and Governmentality. In Cultural Studies, 16 (3) 401-432.

Hultqvist, K. 1998. A History of the Present on Children's Welfare in Sweden: From Föbel to Present-Day Decentralization Projects. In Popkewitz, T. S., Brennan, M. (eds.). Foucault's Challenge: Discourse, Knowledge, and Power in Education. New York and London: Teachers College, 91-116.

Liessmann, K, P. 2009. Teorie nevzdělanosti. Omyly společnosti vědění. [Theorie der Unbildung. Die Irrtümer der Wissengesellschaft]. Praha: Academia

Lyotard, J.-F. 1984. The Postmodern Condition: A Report on Knowledge. Minneapolis: University of Minnesota.

Michalovič, P., Minár, P. 1998. Úvod do štrukturalizmu a postštrukturalizmu [An Introduction to Structuralism and Poststructuralism]. Bratislava: Iris.

Neoliberalism and Education. 2007. In International Journal of Qualitative Studies in Education, Special Issue, 20 (3).

Moss, P. 2009. There are Alternatives! Markets and Democratic Experimentalism in Early Childhood Education and Care. Hague: Bertelsmann.

Olssen, M. 2006. Understanding the Mechanisms of Neoliberal Control: Lifelong Learning, Flexibility and Knowledge Capitalism. In International Journal of Lifelong Education, 25 (3): 231-230.

Olssen, M., Peters, M. A. 2005. Neoliberalism, Higher Education and the Knowledge Economy: from the Free Market to Knowledge Capitalism. In Journal of Education Policy, 20 (3): 313-345.

Peters, M. 2001. Education, Enterprise Culture and the Entrepreneurial Self: A Foucauldian Perspective. In Journal of Educational Enquiry, 2 (2): 58-71.

Peters, M., Besley, A.C., Olssen, M., Maurer, S., Weber, S. (eds.). 2009.Governmentality Studies in Education. Rotterdam: Sense Publishers.

Rubenson, K. 2008. OECD Education Policies and World Hegemony. In Mahon, R., McBride, S. (eds.). The OECD and Transnational Governance. Vancouver: UBC Press, 242-259. 
Simons, M. 2007. The 'Renaissance of the University' in the European Knowledge Society. An Exploration of Principled and Governmental Approaches. In Studies in Philosophy and Education, 26 (5): 433-447.

Simons, M., Masschelein, J. 2008.The Governmentalization of Learning and the Assemblage of a Learning Apparatus. In Educational Theory, 58 (4): 391-315.

The Learning Society from the Perspective of Governmentality. 2006. In Educational Philosophy and Theory, Special issue, 38 (4).

Tuschling, A., Engemann, C. 2006. From Education to Lifelong Learning: the Emerging Regime of Learning in the European Union. In Educational Philosophy and Theory, 38 (4): 451-469.

Weber, S., Maurer, S. (eds.). 2006. Gouvernementalität und Erziehungswissenschaft. Wissen-Macht-Transformation.Wiesbaden: VS Verlag.

\section{Authors:}

Ondrej Kaščák, Ph.D., Associate Professor

Branislav Pupala, Ph.D., Professor

Trnava University in Trnava

Faculty of Education

Priemyselná 4

91843 Trnava

Slovakia

Centre for Research in Education

Institute for Research in Social Communication, Slovak Academy of Science

Klemensova 19

81364 Bratislava

Slovakia

Email: okascak@truni.sk; bpupala@truni.sk 